\title{
A case of a 22-month-old boy with necrotizing pneumonia presenting with leukaemoid reaction misdiagnosed as leukaemia: a case report and review of the literature
}

\author{
Shakilu Jumanne ${ }^{1,2}$, Azan Nyundo ${ }^{3}$ \\ 1. Department of Pediatrics \& Child Health, College of Health Sciences, University of Dodoma, P.O. Box 395 \\ Dodoma, Tanzania \\ 2. Department of Pediatrics \& Child Health, Muhimbili National Hospitals, P.O. Box 65000, Dar es Salaam \\ Tanzania \\ 3. Department of Internal Medicine (Psychiatry Division), College of Health Sciences, University of Dodoma \\ P.O. Box 395, Dodoma, Tanzania
}

\section{Background}

\section{Abstract}

Necrotizing pneumonia and hyperleukocytosis, to the extent of that seen in leukaemia, is a rarely reported presentation. The commonest trigger of such a presentation is an inflammatory process caused by an overwhelming infection which leads to bone marrow irritation. However, the misdiagnosis of this clinical entity as leukaemia should be avoided at all costs so as to avoid the anxiety associated with a diagnosis of cancer, both to the patients and their families.

Case presentation

Here, we report the case of a 22-month-old boy who was referred to our Pediatric Oncology Unit (POU). Owing to a high total leukocyte count (TLC) of 98,000 cells/ $\mu$ l, there was a strong suspicion of leukaemia. The boy had been reviewed at another hospital where he presented with fever and cough refractory to the commencement of tuberculosis medications as a result of chest radiography findings. Laboratory investigations performed on admission in the POU were negative for leukaemia and other myeloproliferative disorders. A chest computer tomography (CT) scan was performed to delineate opacification in the right middle lobe. This revealed multiple necrotic and emphysematous foci in line with a diagnosis of necrotizing pneumonia. Subsequently, the patient responded well to a course of piperacillin- tazobactam. The TLC normalized and the cough and fever resolved over a period of 2 weeks.

Conclusion

Here, we describe a particularly rare case of leukaemoid reaction with a massive leukocyte count. Such patients can be easily misdiagnosed as having leukaemia or other myeloproliferative disorders, especially in settings with limited diagnostic availability. Such misdiagnosis can cause undue stress on the patient and their families. Thus, it is important that patients presenting with these symptoms should undergo a thorough review of history, physical examination and a structured workup.

Key Words: Leukaemoid reaction, necrotizing pneumonia, leukaemia, leukocytosis

\section{Introduction}

Leukaemoid reaction (LR) was first documented by Krumbhaar in 1926 in patients with "leukaemia-like" blood pictures characterized by a high total leukocyte count (TLC) ( $\geq 50000$ cells $/ \geq 1$ ) and the presence of myelocytes on peripheral smears ${ }^{1}$. In settings with limited diagnostic capability, it is possible that LR may be misdiagnosed as leukaemia or another form of myeloproliferative disease ${ }^{2}$. Here, we present the case of a 22-month-old boy who was referred to our unit for leukaemia evaluation after an initial complete blood count (CBC) result showed a TLC of 98,000 cells $/ \mu$ l; the patient had also experienced fever and cough for the previous 3 weeks.

\section{Case presentation}

A 22-month-old patient was referred to our unit due to fever, cough and night sweats for a period of 3 weeks. He was initially administered intravenous antibiotics (ampicillin and gentamycin) for 1 week and was then started on medication for tuberculosis (TB) for 2 weeks after a suspicious chest radiograph. A complete blood count (CBC) showed an elevated TLC with a suspicion of leukaemia; this was the primary reason for his referral to our unit.

On physical examination, he showed signs of wasting (his weight was $8.4 \mathrm{~kg}$ and his weight-for-height $\mathrm{Z}$ score was less than -3 standard deviations). The patient was also pale, dyspnoeic with chest indrawing and crackles on the right side of his chest. He was febrile with a temperature of $39.8^{\circ} \mathrm{C}$, tachypnoeic, and tachycardic with an oxygen saturation of $89 \%$ on room air.

Laboratory investigations including a CBC showed a TLC of 103,000 cells/ $\mu \mathrm{l}$ (neutrophils, 84.2\%; lymphocytes, 9.925\%; monocytes, $7.9 \%$ ) and a red blood cell (RBC) count of $2.7 \times 10^{6}$. Other laboratory data included haemoglobin, $5.08 \mathrm{~g} / \mathrm{dl}$; mean corpuscular volume (MCV), $76.1 \mathrm{fl}$; mean corpuscular haemoglobin (MCH), 24.8 pg, MCHC, 32.6 $\mathrm{g} / \mathrm{dl}$, red cell distribution width (RDW), 16.4\%; and a platelet count of $649 \times 106$. A peripheral smear showed hyper-segmented neutrophils, bands, metamyelocytes with microcytic hypochromic RBCs; C-reactive protein (CRP) was $102.5 \mathrm{mg} / \mathrm{l}$. Flow cytometry of bone marrow aspirate was performed for leukaemia and was negative for CD34, 
Table 1: Summary of the laboratory parameters for the patient

\begin{tabular}{|c|c|c|c|c|c|c|c|c|c|}
\hline \multicolumn{10}{|c|}{ Infection screen and other blood work up } \\
\hline Widal test & HIV $1 \& 2$ & $\begin{array}{l}\text { He patitis } \\
\text { B surface } \\
\text { antigen }\end{array}$ & $\begin{array}{l}\text { Hepatitis C } \\
\text { antibody }\end{array}$ & $\begin{array}{l}\text { A } n \text { t i : } \\
\text { streptolysin } \\
0 \text { titer }\end{array}$ & $\begin{array}{l}\text { GeneXpert } \\
\text { of } \\
\text { aspirater for } \\
\text { TB }\end{array}$ & $\begin{array}{l}\text { C-reactive } \\
\text { protein (mg//) }\end{array}$ & $\begin{array}{l}\text { s e r u m } \\
\text { f e rritin } \\
\text { (ummol/l) }\end{array}$ & $\begin{array}{l}\text { S e r u m } \\
\text { Chloride } \\
\text { (mmol/l) }\end{array}$ & $\begin{array}{l}\text { S e r u m } \\
\text { phosphates } \\
\text { (mmol/l) }\end{array}$ \\
\hline Negative & Negative & Negative & Negative & Negative & Negative & 102 & 9 & 99 & 1.35 \\
\hline \multicolumn{10}{|c|}{ Serum chemistry and other blood work up } \\
\hline $\begin{array}{l}\text { Asp a rta te } \\
\text { transaminase } \\
(\mathrm{u} / \mathrm{l})\end{array}$ & $\begin{array}{l}\text { A I a n i n e } \\
\text { transaminase } \\
(u / l)\end{array}$ & $\begin{array}{l}\text { A I k a l i n e } \\
\text { phosphatase } \\
\text { (u/l) }\end{array}$ & $\begin{array}{l}S \text { e r u } \mathrm{m} \\
\text { Creatinine } \\
\text { (ummol/l) }\end{array}$ & $\begin{array}{l}\text { Serum urea } \\
\text { (ummol/I) }\end{array}$ & LDH (u/l) & $\begin{array}{l}\text { Reticulocyte } \\
\text { count }\end{array}$ & $\begin{array}{l}\text { s e r r u } \mathrm{m} \\
\text { globulin }(\mathrm{g} / \\
\text { dl) }\end{array}$ & $\begin{array}{l}\text { S e r u m } \\
\text { S o di i u m } \\
(\mathrm{mmol} / \mathrm{l})\end{array}$ & $\begin{array}{l}\text { S e r u m } \\
\text { Potasium } \\
(\mathrm{mmol} / \mathrm{l})\end{array}$ \\
\hline 42 & 11 & 323 & 34.5 & 1.9 & 745 & $2.4 \%$ & 26 & 137 & 3.9 \\
\hline
\end{tabular}

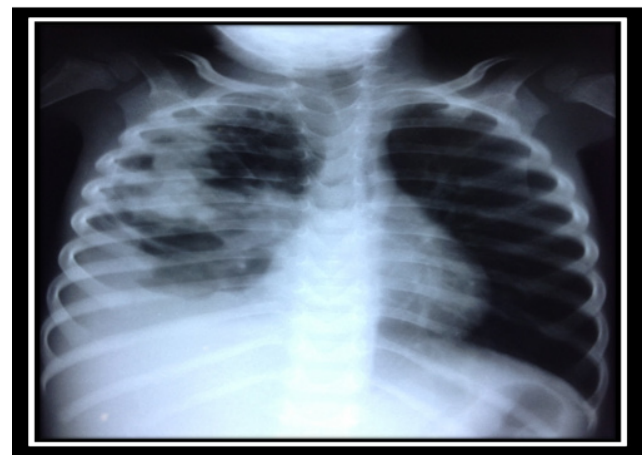

Figure 1: Chest X-ray film of the patient; Chest $\mathrm{x}$-ray film of the patient showing heterogenous opacification (white arrow) in the right middle lobe extending to the lateral aspect of the upper lobe and

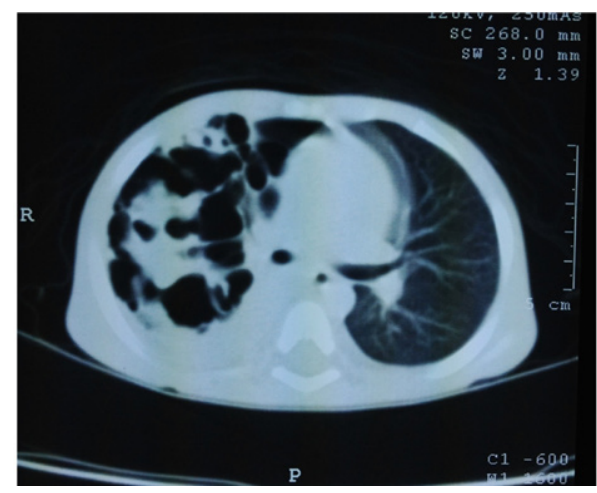

Figure 2: Axial section of Chest CT-scan of the patient; Chest CT-scan lung window view showing areas of consolidation with necrosis (red arrow) and emphysematous components (yellow arrow) in the right middle lung

CD10, CD19, CD117, HLA-DR but positive for CD13, indicating the predominance of mature neutrophils. Other tests were performed and are summarized on Table 1. A chest radiograph (Figure 1) showed heterogeneous opacification in the upper part of the right lower lobe, middle lobe and lateral aspect of the right upper lobe. A subsequent chest computed tomography (CT) scan (Figure 2) showed consolidations in the right middle lobe and upper part of the right lower lobe with emphysematous regions which were suggestive of necrotizing pneumonia.

Blood cultures were negative for bacteria. Based on radiological findings, the patient was empirically started
Table 2: Selected published case reports of Leukemoid reaction with TLC $\geq 100,000 \mathrm{cell} / \mathrm{ul}$

\begin{tabular}{|c|c|c|c|c|}
\hline SN & $\begin{array}{l}\text { A u } \mathrm{th} \text { o } \mathrm{r}(\mathrm{s}) \\
\& \text { year of } \\
\text { publication }\end{array}$ & $\begin{array}{l}\text { Total Leukocyte } \\
\text { count (cells/ul) }\end{array}$ & Underlying diagnosis & Treatment given \& outcome \\
\hline 1 & \begin{tabular}{|l} 
Wang et al, \\
$2017^{6}$
\end{tabular} & $\geq 140,000$ & $\begin{array}{l}\text { Lung Sarcomatoid } \\
\text { carcinoma }\end{array}$ & $\begin{array}{l}\text { Chemotherapy but patient died } \\
\text { two months after diagnosis }\end{array}$ \\
\hline 2 & $\begin{array}{l}\text { Underwood et } \\
{\mathrm{al}, 2012^{7}}\end{array}$ & 116,700 & 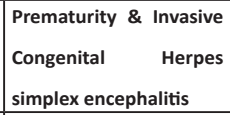 & $\begin{array}{l}\text { IV-Ampicillin, Gentamycin \& } \\
\text { Acyclovir but the baby died } 5 \\
\text { hours later }\end{array}$ \\
\hline 3 & $\begin{array}{l}\text { Foldes C, et al } \\
1981^{8}\end{array}$ & $>100,000$ & $\begin{array}{l}\text { Quinine-induced } \\
\text { hemolysis }\end{array}$ & Undetermined \\
\hline 4 & $\begin{array}{l}\text { Sushanth, K et } \\
\text { al } 2010^{9}\end{array}$ & 145,900 & $\begin{array}{l}\text { Prematurity and MRSA } \\
\text { sepsis }\end{array}$ & $\begin{array}{l}\text { IV antibiotics and supportive } \\
\text { care } \& \text { patient discharged alive } \\
23 \text { days post-admission }\end{array}$ \\
\hline 5 & $\begin{array}{l}\text { Streevatsa A, et } \\
\text { al } 2015^{10}\end{array}$ & 160,000 & $\begin{array}{|lr|}\text { Poorly differentiated } \\
\text { metastatic } & \text { Lung } \\
\text { carcinoma } & \\
\end{array}$ & $\begin{array}{l}\text { Chemotherapy, Radiotherapy } \\
\text { LR resolved, but patient } \\
\text { deteriorated and died two } \\
\text { months later }\end{array}$ \\
\hline 7 & \begin{tabular}{|lrr} 
Leo & $M$, & et \\
al & (Year & not \\
indicated $)^{11}$ &
\end{tabular} & \begin{tabular}{|l|} 
Two cases \\
$1^{\text {st }}$ Case 110,000 \\
$2^{\text {nd }}$ Case 198,000
\end{tabular} & $\begin{array}{l}1^{\text {st }} \text { Case- Gastric ulcer } \\
2^{\text {nd }} \text { Case- } \\
\text { Gastric Carcinama }\end{array}$ & Both patients died \\
\hline 8 & \begin{tabular}{|l|} 
Michael S, et al \\
$1982^{11}$
\end{tabular} & \begin{tabular}{|l|} 
Two case \\
reports
\end{tabular} & Full article unavailable & Undetermined \\
\hline 9 & $\begin{array}{l}\text { Jensen } E \text {, et al } \\
2013^{12}\end{array}$ & $>100,000$ & Prematurity & $\begin{array}{l}\text { No therapy \& spontaneous } \\
\text { resolution }\end{array}$ \\
\hline
\end{tabular}

Table 3: Leukemoid reaction classification using the Hill and Duncan Classification

\begin{tabular}{|c|c|c|}
\hline Bone Marrow stimulation/irritation & $\begin{array}{l}\text { Peripheral circulation } \\
\text { cell demand }\end{array}$ & $\begin{array}{l}\text { Ectopic cytokine } \\
\text { producing sites leading to bone } \\
\text { marrow activation }\end{array}$ \\
\hline $\begin{array}{l}\text { 1.Infections, e.g., Shigellosis, Pertussis, } \\
\text { and Tuberculosis }{ }^{14} \\
\text { 2. Drug-induced e.g. Tigecycline, G-CSF, } \\
\text { Hydroxyurea }^{15}\end{array}$ & $\begin{array}{l}\text { 1. Acute hemolysis } \\
\text { e.g. Sickle cell anemia, } \\
\text { Paroxysmal nocturnal } \\
\text { hemoglobinuria }{ }^{16-18} \\
\text { 2. Bleeding }{ }^{19}\end{array}$ & $\begin{array}{l}\text { 1. Lung cancer }{ }^{20} \\
\text { 2.Oralpharyngial carcinoma }{ }^{21} \\
\text { 3. Gastric Carcinoma }{ }^{22} \\
\text { 4. Lymphoma }{ }^{23}\end{array}$ \\
\hline
\end{tabular}

on piperacillin-tazobactam for necrotizing pneumonia. Three days after the antibiotics were started, the fever and respiratory distress declined, the condition gradually improved, the cough resolved, and the child's weight began to increase. The child was discharged home after 17 days with a normal TLC of 7670 cells $/ \mu 1$. 


\section{Discussion}

LR is a common haematological entity defined as a leukocyte count $\geq 50,000$ cells $/ \mu \mathrm{l}$, predominantly featuring mature neutrophils and a left side shift ${ }^{3}$. In most circumstances, the cause for LR is evident but our case represented a rare scenario in that $L R$, with a TLC $\geq 100,000$ cells/ $\mu$, was misdiagnosed as leukemia ${ }^{4,5}$. It is crucial for clinicians and haematopathologists to distinguish this condition from leukaemia and other myeloproliferative disorders for therapeutic purposes and to avoid causing undue fear among patients and their families caused by a cancer diagnosis. Table 2 summarizes previously published cases of LR with a TLC $\geq 100,000$ cells $/ \geq 1$, along with the underlying diagnoses and outcomes. The aetiopathogenesis of LR can be best summarized by Hill and Duncan's classification which groups the causes of LR into three categories ${ }^{13}$ : increased bone marrow irritation by external factors, response to increased peripheral cellular demand and the ectopic production of stimulating factors causing increased production and differentiation of bone marrow progenitors ${ }^{13}$. Table 3 summarizes the most common causes of LR based on Hill and Duncan's established classification.

The diagnosis of LR requires a thorough medical history and physical examination for signs of infection, acute blood loss and haemolysis; these three factors represent the most common causes ${ }^{24}$. Malignancies and myeloproliferative disorders should also be excluded, particularly in cases with an elevated TLC. Diagnostic evaluations for LR include a CBC, which shows leukocytosis predominantly involving neutrophils, followed by a peripheral blood smear which shows activated neutrophils, bands forms and myelocytes with a left side shift ${ }^{25}$. Our case had elevated levels of serum alkaline phosphatase (ALP), which is usually the case in $\mathrm{LR}^{26}$. Depending on the cause and severity, acute blood loss and/ or haemolysis may be apparent from the medical history; physical examination may also reveal, pallor, jaundice, tachycardia, gallop rhythm, organomegaly and signs of heart failure

Occasionally the cause for LR may not be obvious. Under such circumstances, patients may require additional workup, including bone marrow aspirate/biopsy; in LR these tests show a hypercellular marrow with multilineage cells at variable stages of differentiation ${ }^{27}$. Additional testing of peripheral blood and bone marrow specimens include immunophenotyping for clonal disorders such as leukaemia and the presence of polyclonal mature neutrophils in LR (CD13 and CD15 positivity) and negative CD34, CD117, CD10, CD19 and HLA-DR in leukemia ${ }^{28}$. Another confusing entity for LR is chronic granulocytic leukaemia (CNL) which overlaps with LR in a morphological sense, but its clonal pattern on immunophenotyping clearly distinguishes the two conditions ${ }^{29}$. In order to exclude chronic myeloid leukaemia (CML), it is possible to investigate bone marrow morphology, which shows an arrest in the maturation of myeloid lineage. In addition, it is also possible to carry out cytogenetic evaluation for BCR-ABL; t $(9: 22)^{13}$.

Infectious causes, including bacteria, viruses, and parasites account for the majority of LR cases, thus highlighting the need for an extensive workup. Body fluids and pathological specimens, such as blood, urine, bone marrow, stools, along with pleural and peritoneal fluids should be investigated to detect infectious agents that might cause $\mathrm{LR}^{14}$.

The identification of deep-seated infection foci and tumours require imaging such as ultrasonography, CT scans and magnetic resonance imaging (MRI) ${ }^{15}$. Confirmation of an ectopic cytokine-producing tumour requires the use of Enzyme Linked Immune sorbent Assay (ELISA) for granulocyte colony-stimulating factor (G-CSF), granulocytemacrophage colony-stimulating factor GM-CSF and interleukin (IL)-6 levels ${ }^{16}$. Following the detection and appropriate management of the underlying cause, as with our present case, it is possible for cases of LR to resolve spontaneously ${ }^{17-18}$. Refractory symptoms, which occur despite appropriate therapy for pneumonia, are encountered commonly in the published cases of necrotizing pneumonia; in endemic regions. This might lead to a suspicion of pulmonary tuberculosis, as was the case of our current patient ${ }^{30,31}$.

In conclusion, this case represents a rare situation in which the cause of LR posed a diagnostic challenge to clinicians. Routine clinical evaluations and laboratory investigations may not identify the underlying cause. In such cases, clinicians should actively seek rare causes by broadening their diagnostic workup and perform symptom-directed imaging to rule out malignancies and other rare causes.

\section{Authors' contributions}

SJ was responsible for clinical care for the patient, prepared and revised the manuscript. AN reviewed the manuscript and performed literature review.

\section{Competing interests}

The authors have no competing interests to declare.

\section{Informed consent}

The child's parents provided for their consent for this manuscript to be published, as long as patient details were anonymous.

\section{References}

1. Krumbhaar EB. Leukemoid blood pictures in various clinical conditions. Am J Med Sci. 1926;172:519-33.

2. Au WY, Ma SK, Kwong YL. Disseminated Hepatosplenic Mycobacterial Infection Masking Myeloproliferative Diseases as Leukemoid Reaction: A Diagnostic Pitfall. Leuk Lymphoma. 2001;42(4):805-808. doi:10.3109/10428190109099344

3. Shin HP, Jeon JW, Park JJ, et al. A case of leukemoid reaction in a patient with sarcomatous hepatocellular carcinoma. Korean J Hepatol. 2011;17(3):226-228. doi:10.3350/kjhep.2011.17.3.226

4. George TI. Malignant or benign leukocytosis. Hematol Am Soc Hematol Educ Progr. 2012;2012:475-484. doi:10.1182/ asheducation-2012.1.475

5. Mandal P, Mukherjee SB. Leukemoid Reaction--A Tale of 50 Years. Indian Pediatr. 2015;52(11):973-974. http://www.ncbi.nlm.nih.gov/ pubmed/26615346.

6. Wang D, Zhang H, Yu F, Fang B. Extreme leukocytosis and leukemoid reaction associated with the lung sarcomatoid carcinoma: an unusual case report. Int J Gen Med. 2017;10:7-9. doi:10.2147/IJGM.S102524

7. Underwood MA, Wartell AE, Borghese RA. Hyperleukocytosis in a premature infant with intrauterine herpes simplex encephalitis. J Perinatol. 2012;32(6):469-472. doi:10.1038/jp.2011.138

8. Foldes C, Schaison G, Harousseau JL, Marcelli A. [Major hyperleukocytosis, exceeding 100000 in immune quinine-induced hemolysis (author's transl)]. Ann Pediatr (Paris). 1981;28(9):660-662. http://www.ncbi.nlm.nih.gov/pubmed/7316411.

9. Sushanth, Avabratha KS, Tauro KJ, Shwethadri GK. Hyperleukocytosis in a neonate: A diagnostic dilemma. Indian J Med 
Paediatr Oncol. 2010;31(3):86-88. doi:10.4103/0971-5851.73596

10. Sreevatsa A, Babu SMC, Babu GK, Suresh TM. Hyperleukocytosis, an unusual paraneoplastic manifestation of lung cancer: Case report and review of literature. J Cancer Res Ther. 2015;11(3):669. doi:10.4103/0973-1482.151865

11. Case Report: Marked Mature Neutrophilic Leukocytosis: A Leukemoid Variant Associated with Malignancy. Am J Med Sci. 1982;284(3):32-35. doi:10.1097/00000441-198211000-00005

12. Jansen E, Emmen J, Mohns T, Donker A. Extreme hyperleucocytosis of the premature. BMJ Case Rep. 2013;2013:bcr2012008385. doi:10.1136/bcr-2012-008385

13. Hill, JM, Duncan CN. Classification of leukemoid reactions. Am J Med Sci. 1941;201:847-57.

14. Rahaman MM, JamiulAlam AK, Islam MR, Greenough WB. Shiga bacillus dysentery associated with marked leukocytosis and erythrocyte fragmentation. Johns Hopkins Med J. 1975;136(2):65-70. http://www. ncbi.nlm.nih.gov/pubmed/1090770.

15. Shao Q-Q, Qin L, Ruan G-R, Chen R-X, Luan Z-J, Ma X-J. Tigecycline-induced Drug Fever and Leukemoid Reaction: A Case Report. Medicine (Baltimore). 2015;94(45):e1869. doi:10.1097/ MD.0000000000001869

16. Ko WS, Chen LM, Chao TY, Hwang WS. Myeloblastic leukemoid reaction in paroxysmal nocturnal hemoglobinuria associated with myelodysplasia. Acta Haematol. 1992;87(1-2):75-77. doi: 10.1159/000204721 http://www.ncbi.nlm.nih.gov/pubmed/1585775.

17. Schoenfeld MR. Spiking acid hyperphosphatasia, splenomegaly, and leukemoid reaction during a hemolytic SIckle cell crisis. J Mt Sinai Hosp N Y. 31:212-217. http://www.ncbi.nlm.nih.gov/pubmed/14167678.

18. Mora Alfonso SA, Rodríguez DMC, Londoño JD, Valle-Oñate R, Quintana G. Acute adult-onset still's disease presenting as pulmonary hemorrhage, urticaria, angioedema and leukemoid reaction: a case report and literature review. Springerplus. 2015;4(1):172. doi:10.1186/ s40064-015-0924-8

19. Shalom G, Sion-Vardy N, Dudnik J, Ariad S. Leukemoid reaction in lung cancer patients. Isr Med Assoc J. 2010;12(4):255-256. http://www. ncbi.nlm.nih.gov/pubmed/20803892.

20. Subramaniam N, Hiremath B. Leukemoid reaction as a paraneoplastic syndrome in hypopharyngeal squamous cell carcinoma with cutaneous metastasis: an exceedingly rare occurrence. BMJ Case Rep. 2015;2015:bcr2015211007. doi:10.1136/bcr-2015-211007
21. Kalra M, Dinand V, Sachdeva A, Bhat S, Piplani T, Yadav SP. Pediatric Hodgkin lymphoma presenting with pulmonary nodules and leukemoid reaction. Pediatr Blood Cancer. 2010;55(1):n/a-n/a doi:10.1002/pbc. 22457

22. Sakka V, Tsiodras S, Giamarellos-Bourboulis EJ, Giamarellou H. An update on the etiology and diagnostic evaluation of a leukemoid reaction. Eur J Intern Med. 2006;17(6):394-398. doi:10.1016/j. ejim.2006.04.004

23. Naaraayan A, Aleta M, Basak P, Jesmajian S, Goldstein R. Leukemoid reaction to Clostridium difficile infection. Anaerobe. 2015;34:158-160. doi:10.1016/j.anaerobe.2015.05.005

24. kumar P, Charaniya R, Sahoo R, Tansir G, Sasmal G. Leukemoid Reaction in Chikungunya Fever. J Clin DIAGNOSTIC Res. 2016;10(5):OD05-6. doi:10.7860/JCDR/2016/18434.7720

25. Jardin F, Vasse $M$, Debled $M$, et al. Intense paraneoplastic neutrophilic leukemoid reaction related to a G-CSF-Secreting lung sarcoma. Am J Hematol. 2005;80(3):243-245. doi:10.1002/ajh.20454

26. Johnston A, McFarlane A, Bourner G, Martin T, Padmore R. Distinguishing morphology of reactive versus abnormal neoplastic peripheral blood lymphocytosis. Challenges illustrated by two proficiency testing surveys. Int J Lab Hematol. 2016;38(2):e41-e44. doi:10.1111/ijlh.12469

27. Ramos FJ, Zamora F, Pérez-Sicilia M, Sang MA, del Villar R. Chronic granulocytic leukemia versus neutrophilic leukemoid reaction. Am J Med. 1990;88(1):83-84. http://www.ncbi.nlm.nih.gov/ pubmed/2294772.

28. Butler T, Islam MR, Bardhan PK. The leukemoid reaction in shigellosis. Am J Dis Child. 1984;138(2):162-165. http://www.ncbi. nlm.nih.gov/pubmed/6695872.

29. Li W, Repnikova E. ALK-positive anaplastic large-cell lymphoma with marked leukemoid reaction and hemophagocytic lymphohistiocytosis. Blood. 2016;127(16):2041. http://www.ncbi.nlm. nih.gov/pubmed/27563714.

30. Ramgopal S, Ivan Y, Medsinge A, Saladino RA. Pediatric Necrotizing Pneumonia: A Case Report and Review of the Literature. Pediatr Emerg Care. 2017;33(2):112-115. doi:10.1097/PEC.0000000000000585

31. Sit S-C. Necrotizing Pneumonia in a Young Girl: A Case Report and Literature Review. https://pdfs.semanticscholar.org/eef2/4309befcb149 e4f2be61b4b277adc45a6173.pdf. 